\title{
THE CELLULAR RESPONSE OF THE UTERUS OF THE AGED MOUSE TO OESTROGEN AND PROGESTERONE
}

\author{
C. A. FINN AND L. MARTIN \\ Department of Physiology, The Royal Veterinary College, London, N.W.1, \\ and Department of Hormone Physiology, Imperial Cancer Research Fund, \\ Lincoln's Inn Fields, London, W.C.I
}

(Received 4th August 1969)

The uterus of the aged mouse does not respond to a decidual stimulus as efficiently as that of a young mouse (Finn, 1966a; Talbert \& Krohn, 1966) and it is suggested that this may contribute to the decline of litter size in old mice. In young mice, closure of the uterine lumen (Potts, 1966; Finn \& McLaren, 1967) and stromal cell proliferation (Finn \& Martin, 1967) occur just before implantation, and are probably important in the preparation of the uterus for implantation and decidual cell formation. Both changes can be induced in ovariectomized mice; stromal proliferation by the administration of a small dose of oestrogen following several days' treatment with progesterone (Martin \& Finn, 1968); luminal closure by progesterone alone (Martin, Finn \& Carter, 1970). It was decided, therefore, to determine whether the uterus of the aged mouse can undergo the hormone-induced changes characteristic of the preimplantation uterus.

Previous work has shown that the uterus of a young ovariectomized mouse can be sensitized to respond to a decidual stimulus by the administration of oestrogen and progesterone on the following schedule (Finn, 1966b); Day 1, ovariectomy; Days 3,4 and 5, $0 \cdot 1 \mu \mathrm{g}$ oestradiol daily; Days 7 to $13,1 \mathrm{mg}$ progesterone daily; Day 10, $0.025 \mu \mathrm{g}$ oestradiol at 09.30 hours. In the first experiment, groups of young ( 2 to 3 months) and old (19 to 21 months) randomly-bred albino mice were treated according to this schedule and killed $24 \mathrm{hr}$ after the injection of oestradiol on Day 10. Further groups of young and old mice were treated similarly except that the dose of oestradiol on Day 10 was increased to $0 \cdot 1 \mu \mathrm{g}$. The old mice had been taken from the breeding colony at about 1 year old, and then kept until the start of the experiment. From previous work it is known that mice of this age would have ceased producing young (Biggers, Finn \& McLaren, 1962). Colcemid (0.1 mg) was injected subcutaneously $2 \mathrm{hr}$ before autopsy, the uteri were fixed in Bouin's fluid, and transverse sections were prepared in the normal way and stained with Weigert's iron haematoxylin. One section taken at random from each uterus was examined and the number of cells undergoing mitosis in the luminal and glandular epithelia and in the stroma were counted. In uteri fixed in Bouin's fluid, the opposed epithelia of the closed lumina were pulled apart. The epithelial 
surfaces had a corrugated appearance. The extent of the corrugation was scored at 0,1 or 2 according to the criteria described previously (Martin et al., 1970) to give a measure of luminal closure. The results are shown in Table 1. With the low dose of oestradiol, there was no significant difference between the mean number of cells undergoing mitosis in any of the tissues. With the higher dose

TABLE 1

THE GELLULAR RESPONSE OF THE UTERUS TO A SINGLE DOSE OF OESTRADIOL-17 $\beta$ AFTER 3 DAYS PRE-TREATMENT WITH 1 MG PROGESTERONE (SIX MICE PER GROUP)

\begin{tabular}{|c|c|c|c|c|}
\hline \multirow{2}{*}{$\underset{\text { (months) }}{\text { Age }}$} & \multirow{2}{*}{$\begin{array}{c}\text { Oestradiol } \\
(\mu g)\end{array}$} & \multicolumn{2}{|c|}{ Mean no. of mitoses/section \pm S.E. } & \multirow{2}{*}{$\begin{array}{l}\text { Corrugation } \\
\text { score }(/ 12)\end{array}$} \\
\hline & & Lumen & Stroma & \\
\hline 2 to 3 & $\begin{array}{l}0.02 \\
0.1\end{array}$ & $\begin{array}{l}0.1 \pm 0.1 \\
7.8 \pm 2.7\end{array}$ & $\begin{array}{l}50 \cdot 3 \pm 8 \cdot 0 \\
67 \cdot 5 \pm 4 \cdot 1\end{array}$ & $\begin{array}{l}10 \\
11\end{array}$ \\
\hline 19 to 21 & $\begin{array}{l}0 \cdot 02 \\
0 \cdot 1\end{array}$ & $\begin{array}{r}0.5 \pm 0.5 \\
10.4 \pm 4.0\end{array}$ & $\begin{array}{r}61 \cdot 3 \pm 21 \cdot 1 \\
132 \cdot 8 \pm 24 \cdot 8\end{array}$ & $\begin{array}{l}2 \\
0\end{array}$ \\
\hline
\end{tabular}

The number of mitoses in the glands did not differ significantly from zero in any group.

of oestrogen, there were significantly more stromal cells in mitosis in the old than in the young uteri. The extent of corrugation of the luminal surface differed considerably between the young and old mice. The uteri of the old animals showed little evidence of corrugation, whereas the young animals showed good corrugation. The orientation of the lumen also differed. All the young animals had slit-like lumina orientated in a mesometrial-antimesometrial plane typical of early pregnancy; three of the old uteri had fairly normal-looking lumina, but in the remainder the lumina were irregular in cross section.

\section{TABLE 2}

THE GELLULAR RESPONSE OF THE UTERUS TO A SINGLE INJECTION OF $0.02 \mu \mathrm{G}$ OESTRADIOL- $17 \beta$ IN ANIMALS NOT PRE-TREATED WITH PROGESTERONE

\begin{tabular}{c|c|ccc}
\hline \multirow{2}{*}{ Age (months) } & \multirow{2}{*}{$\begin{array}{c}\text { No. of } \\
\text { mice }\end{array}$} & \multicolumn{3}{|c}{ Mean no. of mitoses per section $\pm S . E}$. \\
\cline { 2 - 5 } & & Lumen & Glands & Stroma \\
\hline 2 to 3 & 7 & $12 \cdot 7 \pm 2 \cdot 5$ & $8 \cdot 6 \pm 2 \cdot 0$ & $1 \cdot 7 \pm 1 \cdot 0$ \\
19 to 21 & 5 & $34 \cdot 8 \pm 13 \cdot 5$ & $50 \cdot 6 \pm 9 \cdot 0$ & $0 \cdot 8 \pm 0 \cdot 4$ \\
\hline
\end{tabular}

The corrugation score was zero in all animals.

From these results, it appears that the stromal cells of the old uterus are still capable of responding to oestrogen and progesterone by proliferation. In view of this, it was decided to investigate the mitotic response of the uterus to oestrogen alone. Groups of old and young mice were treated as in the schedule except that the administration of progesterone was omitted. The number of mitoses in the tissues of the uteri are shown in Table 2. The pattern of response is similar in the two groups, cell division being confined to the epithelia of the 
PI.TTE 1
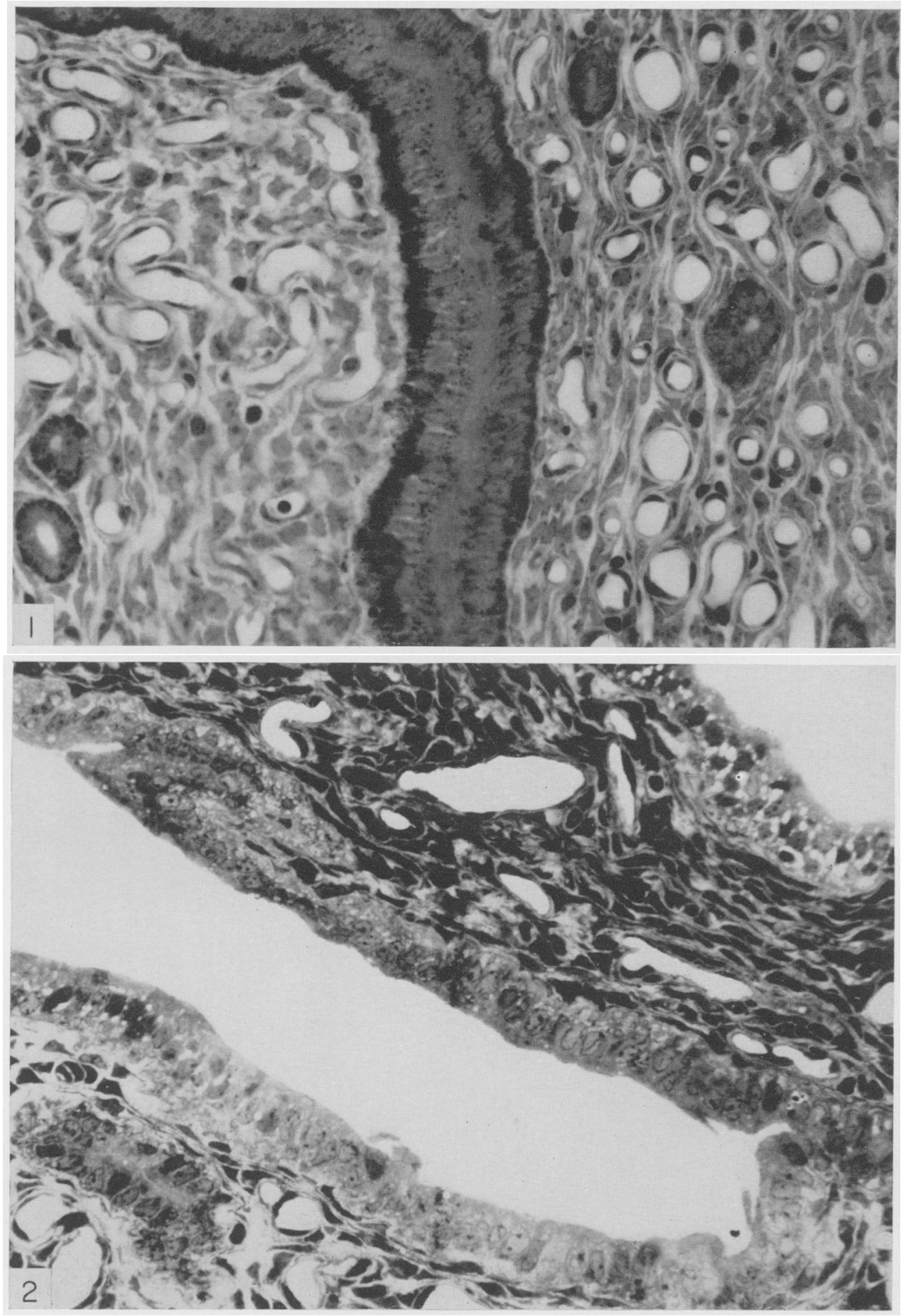

Fis. 1. Transwerse section through enctometrium of venng mouse after treatment with

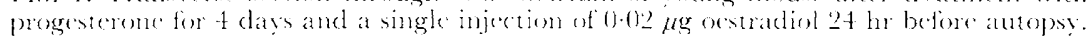
Fixation was by perfusion of glutanalebyede with subseguent immersion in osmium and araldite anbedeling.

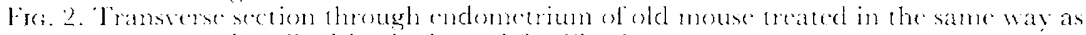

the young mouse described in the legend for lig. le fown foaded from Bioscientifica.com at 04/26/2023 01:38:39AM 
lumina and glands. The response in the old mice was greater than in the young, demonstrating that the ability of the cells of the endometrium to divide is not impaired in old mice.

In order to confirm that the absence of corrugation of the free surface of the luminal epithelial cells was associated with failure of the lumen to close, groups of old and young mice were treated as in the schedule and the uteri fixed by perfusion of formol Tyrode followed by glutaraldehyde through the descending aorta. Pieces of uteri were post-fixed in osmium and embedded in araldite. This procedure does not cause separation of the epithelial surfaces. Sections were examined using both the light microscope and the electron microscope. All of the uteri from ten young mice showed complete closure of the lumen (Pl. 1, Fig. 1), whereas only one of six old animals had a closed lumen (PI. 1, Fig. 2).

The failure of the uterine lumen to close in response to progesterone and the irregular orientation of the lumen may be important factors in the failure of blastocysts to implant in old uteri and the lack of response to intraluminal decidual stimuli.

\section{REFERENCES}

Biggers, J. D., Finn, C. A. \& McLaren, A. (1962) Long term reproductive performance of female mice. I. Effect of removing one ovary. F. Reprod. Fert. 3, 303.

Fins, C. A. (1966a) The initiation of the decidual cell reaction in the uterus of the aged mouse. $\mathcal{F}$. Reprod. Fert. 11, 423.

Fins, C. A. (1966b) Endocrine control of endometrial sensitivity during the induction of the decidual cell reaction in the mouse. 7. Endocr. 36, 239.

Finn, C. A. \& McLaren, A. (1967) A study of the early stages of implantation in mice. 7. Reprod. Fert. $13,259$.

Finn, C. A. \& Martin, L. (1967) Patterns of cell division in the mouse uterus during early pregnancy. F. Endocr. 39, 593.

Martin, L. \& Fins, C. A. (1968) Hormonal regulation of cell division in epithelial and connective tissues of the mouse uterus. $\mathcal{F}$. Endocr. 41, 363.

Martin, L., Finn, G. A. \& Carter, J. (1970) The effects of progesterone and oestradiol-17 $\beta$ on the luminal epithelium of the mouse uterus. F. Reprod. Fert. 21 (In press).

Potrs, M. (1966) The attachment phase of ovoimplantation. Am. F. Obstet. Gynec. 96, 1122.

TALBERT, G. B. \& Krohn, P. L. (1966) Effect of maternal age on viability of ova and uterine support of pregnancy in mice. F. Reprod. Fert. 11, 399. 